\title{
Ocean warming expands habitat of a rich natural resource and benefits a national economy
}

Jansen, Teunis; Post, Søren Lorenzen; Kristiansen, Trond; Oskarsson, Gudmundur J.; Boje, Jesper; MacKenzie, Brian R.; Broberg, Mala; Siegstad, Helle

\author{
Published in: \\ Ecological Applications
}

Link to article, DOI:

10.1002/eap.1384

Publication date:

2016

Document Version

Publisher's PDF, also known as Version of record

Link back to DTU Orbit

Citation (APA):

Jansen, T., Post, S. L., Kristiansen, T., Oskarsson, G. J., Boje, J., MacKenzie, B. R., Broberg, M., \& Siegstad, H. (2016). Ocean warming expands habitat of a rich natural resource and benefits a national economy. Ecological Applications, 26(7), 2021-2032. https://doi.org/10.1002/eap.1384

\section{General rights}

Copyright and moral rights for the publications made accessible in the public portal are retained by the authors and/or other copyright owners and it is a condition of accessing publications that users recognise and abide by the legal requirements associated with these rights.

- Users may download and print one copy of any publication from the public portal for the purpose of private study or research.

- You may not further distribute the material or use it for any profit-making activity or commercial gain

- You may freely distribute the URL identifying the publication in the public portal 


\title{
Ocean warming expands habitat of a rich natural resource and benefits a national economy
}

\author{
Teunis Jansen, ${ }^{1,2,6}$ Søren Post, ${ }^{1}$ Trond Kristiansen, ${ }^{3}$ Guðmundur J. Óskarsson, ${ }^{4}$ Jesper Boje, ${ }^{1,2}$ \\ Brian R. MacKenzie, ${ }^{5}$ Mala Broberg, ${ }^{1}$ and Helle Siegstad ${ }^{1}$ \\ ${ }^{1}$ GINR - Greenland Institute of Natural Resources, 3900 Nuuk, Greenland \\ ${ }^{2}$ DTU AQUA - National Institute of Aquatic Resources, 2920 Charlottenlund, Denmark \\ ${ }^{3}$ IMR-Institute of Marine Research, Box 1870, Nordnes, N-5817 Bergen, Norway \\ ${ }^{4}$ MRI-Marine Research Institute, PO Box 1390, Skulagata 4, 121 Reykjavik, Iceland \\ ${ }^{5}$ Center for Ocean Life, National Institute for Aquatic Resources (DTU Aqua), Technical University of Denmark, \\ DK 2920 Charlottelund, Denmark
}

\begin{abstract}
Geographic redistribution of living natural resources changes access and thereby harvesting opportunities between countries. Internationally shared fish resources can be sensitive to shifts in the marine environment and this may have great impact on the economies of countries and regions that rely most heavily on fisheries to provide employment and food supply. Here we present a climate change-related biotic expansion of a rich natural resource with substantial economic consequences, namely the appearance of northeast Atlantic mackerel (Scomber scombrus) in Greenlandic waters. In recent years, the summer temperature has reached record highs in the Irminger Current, and this development has expanded the available and realized mackerel habitat in time and space. Observations in the Irminger Current in east Greenland in 2011 of this temperature-sensitive epipelagic fish were the first records so far northwest in the Atlantic. This change in migration pattern was followed by a rapid development of a large-scale fishery of substantial importance for the national economy of Greenland ( $23 \%$ of Greenland's export value of all goods in 2014). A pelagic trawl survey was conducted in mid-summer 2014 and the results showed that the bulk of $\sim 1$ million $\mathrm{Mg}(=\mathrm{t})$ of mackerel in the Irminger Current in southeast Greenland were located in the relatively warm $\left(>8.5^{\circ} \mathrm{C}\right)$ surface layer. Mackerel was also observed in southwest Greenland. Finally, 15 CMIP5 Earth System Model projections of future marine climate were used to evaluate the epipelagic environment in Greenland. These projections for moderate and high $\mathrm{CO}_{2}$ emission scenarios (representative concentration pathways $[\mathrm{RCP}] 4.5$ and 8.5 ) suggest how the available mackerel habitat may expand further in space and time. Overall, our results indicate that, if the stock remains large, productive, and continues its current migration pattern, then climate change has provided Greenland with a new unique opportunity for commercial exploitation. However, positive cases like this should not be cherry-picked and misused as arguments against timely and effective mitigation of climate change.
\end{abstract}

Key words: climate change; CMIP 5; Greenland; mackerel (Scomber scombrus); Northeast Atlantic; projection.

\section{INTRODUCTION}

Many species, including commercially important fish species, are undergoing phenological and geographical shifts as a result of warming (IPCC 2014, Gattuso et al. 2015). The geographic redistribution of natural resources changes the access and thereby harvesting opportunities between countries and regions. Such shifts in the marine environment are therefore expected to have impact on the economy of countries and regions that mostly rely on fisheries (Barange et al. 2014). Pelagic ecosystems are highly sensitive to climate change (Beaugrand 2014), and since the projected rise in ocean temperature over the 21 st

Manuscript received 12 September 2015; revised 18 January 2016; accepted 21 March 2016; final version received 9 May 2016. Corresponding Editor: O. Jensen.

${ }^{6}$ E-mail: Tej@aqua.dtu.dk century is generally expected to be largest near the surface (IPCC 2014), we expect the epipelagic (upper water column) species to respond first.

The epipelagic fish, northeast Atlantic mackerel (Scomber scombrus), is one of the most abundant and widely distributed migratory fish species in the North Atlantic Ocean (Trenkel et al. 2014). Mackerel has functional roles in marine ecosystems as both a major zooplanktivore and as prey for higher trophic levels (Trenkel et al. 2014). It is also one of the most economically important fish species of the North Atlantic, particularly for countries such as Denmark, Faroe Islands, Iceland, Ireland, Norway, and Scotland. Mackerel populations occur on both sides of the North Atlantic (Jansen and Gislason 2013). The northeast Atlantic (NEA) mackerel are known to spawn between Portugal in the south, Iceland in the northwest, and Sweden in the east (Fig. 1). Spawning starts in January/ 


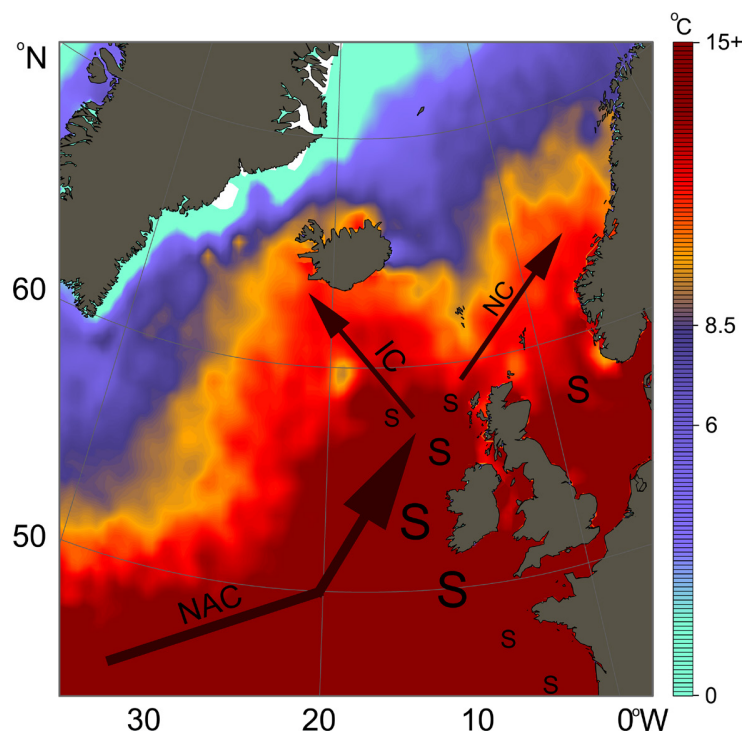

FIG. 1. Northeast Atlantic Ocean. Black arrows indicate the main warm surface currents: the North Atlantic Current (NAC), the Irminger Current (IC), and the Norwegian Current (NC). The majority of the northeast Atlantic (NEA) mackerel (Scomber scombrus) follow the IC and NC in northerly directions in spring and early summer from the spawning areas (indicated by "S") to the feeding areas. Background indicates the mean sea surface temperature (SST) from the 13 to 25 June 2014, when the 2014 fishing season started in Greenlandic waters. Temperature color scale is provided to the right of the map.

February in Iberian Peninsula waters and ends in July in the northern areas (Jansen et al. 2009). Mackerel live their entire life in the pelagic environment, starting with the early life stages (eggs and young larvae). Young juveniles begin to migrate horizontally, and mature adult individuals perform extensive horizontal migrations between spawning grounds, feeding grounds, and overwintering areas (Trenkel et al. 2014). The migration pattern has varied considerably through history, demonstrating the spatial plasticity of the species (Allen 1897, Astthorsson et al. 2012, Jansen 2014). In recent years, the majority of the mackerel feeding migration has followed the North Atlantic Current as it braches into the Norwegian and Irminger Currents (Fig. 1). Mackerel migration has historically been linked to temperature variability (Jansen and Gislason 2011, Overholtz et al. 2011, Jansen et al. 2012, Radlinski et al. 2013). Feeding migration during summer is only very rarely observed in waters colder than $\sim 6^{\circ} \mathrm{C}$, and the mackerel are most abundant in the $8-13^{\circ} \mathrm{C}$ range (Utne et al. 2014, Berge et al. 2015). Temperature is thus an important factor for mackerel distribution. However, other drivers affect the migration as well, such as feeding opportunities (and hence mackerel density in areas of top-down trophic control) and surface currents (Jansen 2014). An available habitat with suitable temperatures therefore may not be populated, for example, during periods of low stock levels or unfavorable food conditions (Jansen 2014).

The mackerel fishery has changed drastically since 2007, when the summer distribution began expanding in the Nordic Seas (ICES 2013). The expansion led to increased exploitation by some of the countries that already possessed internationally agreed quotas, as well as new emergent fisheries by countries located at the northwestern extreme of the mackerel migration path. Since then, the mackerel-fishing countries have not been able to agree on a comprehensive international agreement despite multiple annual attempts (Jensen et al. 2015). This has led to increasing political tension between the European Union, Russia, Norway, Faroe Islands, Iceland, and Greenland, culminating in international sanctions (Bazilchuk 2010, Cendrowicz 2010, Jensen et al. 2015) and overfishing of one of the most important living marine resources in the Atlantic (ICES 2014). During recent years, the total international catch has exceeded the ICES quota advice by $48 \%$ (average 2010 2014; ICES 2014). More knowledge about the mackerel expansion is therefore urgently needed to facilitate reconciliation, and to provide the basis for a sustainable management framework that can be supported by all stakeholders. Given that climate change is going to have similar effects on other commercially important marine fish species in the global ocean (i.e., habitat expansions to new fishing jurisdictions, with potential for disagreements among authorities regarding resource allocation and access), the example of mackerel in the NEA could be a useful case study to illustrate and learn how the changing ecology of the species and ecosystems can impact fishery and ecosystem management policies. Such policies will need a strong scientific basis on which decisions can be based.

Here we present the arrival and distribution of mackerel in Greenlandic waters, which has not been described in the primary literature before. We explore the role of warming on the habitat expansion and new migration patterns, and provide historical perspectives of the size and seasonal duration of the available habitat. We then provide a future outlook for the oceanographic conditions for mackerel presence near Greenland by presenting future marine climate scenarios to 2100 in detail for this part of the North Atlantic. Finally, we assess the importance of mackerel for the Greenlandic economy.

\section{Materials And Methods}

\section{Pelagic trawl survey}

A research survey was conducted with R/V Árni Friðriksson in mid-summer 2014 as a part of the International Ecosystem Summer Survey in the Nordic Seas (IESSNS). The survey covered the Greenlandic Exclusive Economic Zone (EEZ) off the east coast, from $65^{\prime} 06^{\circ} \mathrm{N}$ to $58^{\prime} 36^{\circ} \mathrm{N}$, (Fig. 2) from 30 July to 11 August. Thirty-eight surface trawl hauls were taken with 50-60 nmi (nautical mile $=1,852$ meters) intervals. The survey protocol is available in Valdemarsen et al. (2014) and Nøttestad et al. (2015b). The density of mackerel $\left(\mathrm{kg} / \mathrm{nmi}^{2}\right)$ was estimated for each trawl haul by dividing 


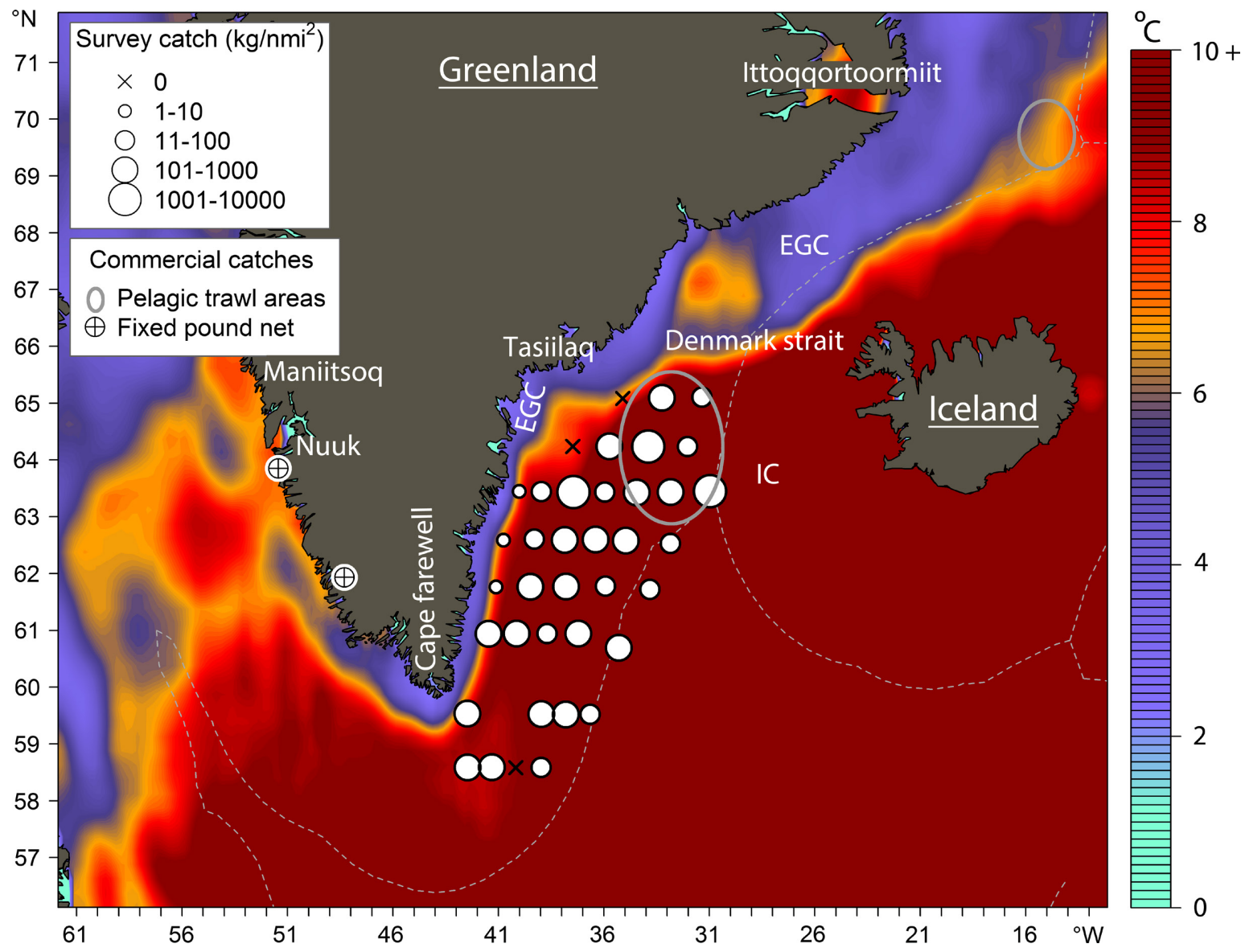

FIG. 2. Mackerel observations in Greenland overlaid on sea surface temperatures measured by satellite in August 2014 (NOAA OI data). Oceanic catches were caught using pelagic trawls by research vessels during survey in mid-summer 2014 (white circles with black borders and black crosses) and by commercial vessels from June to September 2014 (open gray ovals). Coastal catches in fixed pound nets were taken in September 2013 (white circles with black crosshairs). The temperature color scale differs from Fig. 1 and is provided to the right of the map. EGC stands for East Greenland Current. "Warm" colors (orange-red) indicate potential mackerel presence $\left(>6^{\circ} \mathrm{C}\right)$, and dark red colors indicate mackerel habitat $\left(>8.5^{\circ} \mathrm{C}\right)$.

the total catch of mackerel $(\mathrm{kg})$ with an estimate of swept area (trawl haul distance $\times$ horizontal opening of the trawl; Valdemarsen et al. 2014, Nøttestad et al. 2015b).

\section{Commercial fisheries}

Logbook data containing date, position, and mass of all commercial mackerel catches were provided by Greenland Fisheries License Control (database version 25 November 2014) i.e., after the ending of the mackerel fishery in 2014. The catches were from pelagic trawling, except a few individual mackerel caught in fixed pound nets. A random subset of the catches was sampled onboard pelagic trawlers by the fishermen in 2012-2014. Ten to 200 mackerel were sampled randomly from each catch and measured (total length rounded down to the nearest centimeter). Specimens from two coastal catches in fixed pound nets in September 2013 were sent to the Greenland Institute for Natural Resources (GINR), where the mackerel were length measured.
The importance of mackerel landings to the Greenland economy was assessed. The total export value (all types of goods) in 2012-2013 was obtained from Greenland's official statistics (Greenland Statistics 2014). The total export values from 2010 and 2011 were not available, so they were assumed to equal the average of 2012 and 2013. The value of the landings was calculated using an approximate average price of 8 DKK (Danish crowns) per kilo mackerel (Greenland Statistics 2014). Conversion between DKK and Euro $(€)$ was done using the exchange rate 7.5 DKK $=1 €$ obtained from the European Central bank on 3 March 2015.

\section{Hydrographic data}

A data set of historic sea surface temperatures (SST) from 1870 to 2013 was obtained from the Hadley Centre (data available online). ${ }^{7}$ The HadISST1 temperatures are

\footnotetext{
${ }^{7}$ www.metoffice.gov.uk/hadobs/hadisst/
} 
TABLE 1. Climate models used in the present analysis.

\begin{tabular}{|c|c|c|c|c|c|c|}
\hline Model & Rip & $\mathrm{RCP} 4.5$ & $\mathrm{RCP} 8.0$ & $\overline{\Delta T}\left({ }^{\circ} \mathrm{C}\right)$ & $R_{\mathrm{ma}}$ & Source \\
\hline IPSL-CM5A & r1ilp1 & $\mathrm{X}$ & $\mathrm{X}$ & 1.4 & 0.59 & Institut Pierre Simon Laplace, France \\
\hline BCC-CSM1 & rlilp1 & & $\mathrm{X}$ & 5.9 & 0.45 & $\begin{array}{l}\text { Beijing Climate Center Climate System Model, } \\
\text { China }\end{array}$ \\
\hline MPI-ESM & rlilp1 & $\mathrm{X}$ & $\mathrm{X}$ & -1.5 & 0.35 & Max-Plack-Institut fur Meteorologie, Germany \\
\hline INMCM4 & rlilp1 & $\mathrm{X}$ & $\mathrm{X}$ & 1.8 & 0.23 & Institute of Numerical Mathematics, Russia \\
\hline GFDL-ESM2M & rlilp1 & & $\mathrm{X}$ & -1.0 & 0.2 & $\begin{array}{l}\text { Geophysical Fluid Dynamics Laboratory, } \\
\text { NOAA, USA }\end{array}$ \\
\hline CanESM2 & rlilp1 & $\mathrm{X}$ & $\mathrm{X}$ & 0.2 & 0.06 & $\begin{array}{l}\text { Canadian Centre for climate modelling and } \\
\text { analysis, Canada }\end{array}$ \\
\hline HadGEM2 & rlilp1 & & $\mathrm{X}$ & -0.5 & 0.05 & Hadley Centre, UK \\
\hline NorESM1-M & rlilp1 & $\mathrm{X}$ & $\mathrm{X}$ & -1.1 & -0.04 & Norwegian Climate Center, Norway \\
\hline CESM1 & rlilp1 & & $\mathrm{X}$ & -1.8 & -0.07 & National Center for Atmospheric Research, USA \\
\hline GFDL-ESM2G & rlilp1 & & $\mathrm{X}$ & 2.7 & -0.19 & $\begin{array}{l}\text { Geophysical Fluid Dynamics Laboratory, } \\
\text { NOAA, USA }\end{array}$ \\
\hline
\end{tabular}

Notes: $\mathrm{X}$ indicates that model outputs were available for the specified representative concentration pathway (RCP) scenario experiments. Model output diagnostics $\left(\overline{\Delta T}\right.$ and $\left.R_{\mathrm{ma}}\right)$ were derived from a comparison between historical hindcasts and the observation based time series (HadISST1), $\overline{\Delta T}$ is the average annual temperature difference in 1982-2013 (the values used for bias correction), and $R_{\mathrm{ma}}$ is the correlation coefficient between multidecadal patterns (20-yr moving averages). Ensemble member (rip) as defined in http://cmip-pcmdi.llnl.gov/cmip5/docs/cmip5_data_reference_syntax.pdf. See Appendix S3 for further details.

based on in situ measurements and contain global monthly estimates of SST at $1^{\circ}$ longitude $\times 1^{\circ}$ latitude resolution (Rayner et al. 2003). The data set was created by the Hadley Centre using the interpolation procedure described by Rayner et al. (2003). This data set was used to compare hindcast simulations from climate models as well as to biascorrect the climate predictions (see following paragraphs).

A high-resolution data set of SST from recent years (2010-2014) was obtained from NOAA/OAR/ESRL PSD (Boulder, Colorado, USA). The NOAA optimum interpolation 1/4 degree daily sea surface temperature analysis data is a high-resolution optimal interpolation of SST measures by satellite-based AVHRR sensors (advanced very high resolution radiometer; Reynolds et al. 2007).

Temperature data were collected in vicinity of all the 38 pelagic trawl stations in the IESSNS survey in August 2014 (Fig. 2). Temperature data were collected while lowering a Sea-Bird CTD sensor (Sea-Bird Electronics, Inc., Bellevue, Washington, USA) with a water rosette from the surface down to $500 \mathrm{~m}$ depth, or to $10 \mathrm{~m}$ above the bottom in areas $<500 \mathrm{~m}$. The temperature was recorded during the descent. The accuracies of the temperature and pressure measurements were $0.001^{\circ} \mathrm{C}$ and 3,000 pascal, respectively.

During the last few decades, global climate models (GCM) have improved tremendously in their ability to model the climate system of the globe (Reichler and Kim 2008). GCMs couple the general circulation of the atmosphere and the oceans to simulate global climate conditions. The latest climate models, earth system models (ESM), also connect the physics of GCMs with atmospheric and ocean chemistry, carbon cycle, changes in land use and land cover, vegetation, and human activities to provide climate projections for the future. This study used both GCMs and ESM projections from the fifth phase of the coupled model inter-comparison project (CMIP5) to analyze future conditions of the ocean temperature around Greenland. Most of the climate models referred to here used different spatial resolutions both in the ocean and atmosphere, but for the majority the resolutions were $1^{\circ} \times 1^{\circ}$ (longitude $\times$ latitude) in the ocean and $2.5^{\circ} \times 2.5^{\circ}$ resolution in the atmosphere. Future climate predictions depend on potential greenhouse gas trajectories, adopted as the representative concentration pathways (RCP) by the IPCC for its fifth assessment report (Collins et al. 2013). Four different RCP scenarios are available and describe possible future climates depending on the amount of greenhouse gases emitted into the atmosphere. Here we present an optimistic scenario RCP 4.5 and the "worst business-as-usual scenario," RCP 8.5. The RCP scenarios are defined as the global average heat increase by year $2100\left(4.5\right.$ and $\left.8.5 \mathrm{~W} / \mathrm{m}^{2}\right)$. This corresponds to an expected rise in global atmospheric temperatures of $1.1-2.6^{\circ} \mathrm{C}$ for the RCP 4.5 scenario, and between $2.6^{\circ} \mathrm{C}$ and $4.8^{\circ} \mathrm{C}$ for the RCP 8.5 scenario (IPCC 2014).

Modeled climate data for both the past and the future (1850-2100) were obtained from the CMIP5 (https:// pcmdi.llnl.gov/search/cmip5/). SST data from 10 different ESMs were downloaded (Table 1). Each model was re-gridded to a standard global rectangular grid $\left(360^{\circ} \times 180^{\circ}\right.$, longitude $\times$ latitude $)$ using the Climate

\footnotetext{
${ }^{8}$ https://code.zmaw.de/projects/cdo
} 
TABle 2. Commercial catches of Atlantic mackerel (Scomber scombrus) in Greenland.

\begin{tabular}{lccc}
\hline \hline Year & $\begin{array}{c}\text { Catch } \\
\text { Mg }(=\mathrm{t})\end{array}$ & $\begin{array}{c}\text { Catch value } \\
(\text { million } € \text { ) }\end{array}$ & Export value $(\%)$ \\
\hline 2011 & 0.16 & 0 & 0 \\
2012 & 7.4 & 8 & 3 \\
2013 & 54.15 & 58 & 15 \\
2014 & 78.58 & 84 & 23
\end{tabular}

Note: The approximate value of the landings is given in euros, and as a percentage of Greenland's total export (all goods).

Data Operators toolbox that allows for weighted bilinear interpolation between grids (program available online). ${ }^{8}$

CMIP5 models of SST are known to be cold/warmbiased in some areas (Steinacher et al. 2010), such as the present study area around south Greenland. The bias depends on how the climate models capture the stratification of the Labrador Sea and the areas south of Greenland. If strong stratification is consistent in the model, the cold water flowing south from the Arctic (the East Greenland Current) is capped at the top of the water column and prevented from sinking through convection. This creates very cold regions south of Greenland. To correct for this, the CMIP5 temperature model outputs were bias corrected using the difference between the modeled (CMIP5) and the observed (HadISST1) climatologies $(\overline{\Delta T}) \cdot \overline{\Delta T}$ were calculated for each model for the period 1982-2013 (the years where HadISST1 was based on high resolution satellite measurements) for the mackerel fishing area $\left(63.5^{\circ} \mathrm{N}, 31.5^{\circ} \mathrm{W}\right)$ and season (July-August). The selection of years used for the bias correction was not biased toward high or low temperatures, because it spanned both a relatively cold $15-\mathrm{yr}$ period (1982-1997) and a relatively warm 15-yr period (1998-2013). The bias correction was applied to the entire time series.

Maps and depth profiles were plotted using the filled.contour () function in the base-package of R v.3.1.0 (R Core Team 2013). The data used for each figure was described in the corresponding figure legend.

Time series of modeled (CMIP5) and observed (HadISST1) SST were presented for three focus areas representing (1) the mackerel fishing area in southeast Greenland $\left(63.5^{\circ} \mathrm{N}, 31.5^{\circ} \mathrm{W}\right)$, (2) the area south of Greenland $\left(57-58^{\circ} \mathrm{N}, 44-45^{\circ} \mathrm{W}\right)$, and southwest of Greenland $\left(60-61^{\circ} \mathrm{N}, 53-54^{\circ} \mathrm{W}\right)$.

\section{RESULTS}

\section{Mackerel in Greenland}

For the first time in history, mackerel were observed in Greenland in 2011, where $0.16 \mathrm{Mg}(=\mathrm{t})$ were caught by pelagic trawlers (Table 2). The fishery developed rapidly to include 27 large pelagic freezer trawlers that caught $78 \mathrm{kt}$, worth $\sim 83$ million $€$ (100 million US\$) in 2014, corresponding to $23 \%$ of Greenland's export value of all goods (Table 2). Ninety-three percent of the Greenlandic foreign trade comes from marine fisheries (Jervelund and Fredslund 2013).

The commercial catches of mackerel in Greenland waters were taken in an area south of Denmark Strait (Fig. 2, gray oval south of $67^{\circ} \mathrm{N}$ ), until September 2014, where $14 \mathrm{Mg}(=\mathrm{t})$ were caught in the herring fishery east of Ittoqqortoormiit $\left(69-70.5^{\circ} \mathrm{N}\right.$; Fig. 2, gray oval north of $69^{\circ} \mathrm{N}$, east of $17^{\circ} \mathrm{W}$ ). Information from coastal fishermen had furthermore suggested mackerel occurrences close to land from $65.6^{\circ} \mathrm{N}$ on the east coast (Tasiilaq) to $65.4^{\circ} \mathrm{N}$ on the west coast (Maniitsoq) in recent years. In September 2013, the coastal occurrence of mackerel in southwest Greenland was confirmed by samples from fixed pound nets $\left(61.9-63.9^{\circ} \mathrm{N}, 48.3-51.4^{\circ} \mathrm{W}\right.$, Fig. 2).

A pelagic trawl survey was conducted in late June to early August 2014 in the area from Denmark Strait to Cape Farewell. Mackerel was, with a few exceptions, found throughout the area (Fig. 2, black circles). The average catch rate was $3.5 \mathrm{t} / \mathrm{km}^{2}$ and the survey area was 335 million $\mathrm{m}^{2}$. This corresponds to a swept area estimate of $1164 \mathrm{kt}$ of mackerel in the surveyed part of Greenland's EEZ.

The mackerel in Greenland consisted mainly of adult mackerel (Fig. 3a). The youngest mackerel caught in the survey were $2 \mathrm{yr}$ old. Only one of the mackerel sampled from commercial catches were smaller $(16 \mathrm{~cm})$ than the mean length juvenile mackerel at the end of their first growth season (20 cm; Jansen and Burns 2015).

The average size of the mackerel in the fishery increased during the fishing season; late June to early September (Fig. 3a). This trend has been evident every year (Fig. 3b, c), except for 2014, where a substantial fraction of smaller $(30-33 \mathrm{~cm})$ fish were present in July 2014 (Fig. 3b). The survey in mid-summer 2014 indicated a core of smaller fish extending from the northeast, surrounded by larger fish to the west, south, and southeast (Fig. 4).

Commercial fishermen reported catches of mackerel that appeared to be in a state of spawning in June 2014. These observations were not quantified, nor confirmed histologically. However, images of ripe gonads (presumably with hydrated eggs) from fish in a single catch were provided by the industry (Appendix S1). The gonads of 139 mackerel were therefore inspected and weighed to estimate timing of the spawning season in Greenland. However, none of the sampled mackerel were in spawning condition. The rarity of observations of spawning and juveniles strongly indicated that Greenland was not a recruitment and nursery area up to 2014 .

\section{Available and realized mackerel habitat according to hydrography}

The pelagic survey covered waters where the surface temperature (mean temperature in $0-5 \mathrm{~m}$ depth) was between $4.3^{\circ} \mathrm{C}$ and $11.3^{\circ} \mathrm{C}$. Mackerel were caught in low 

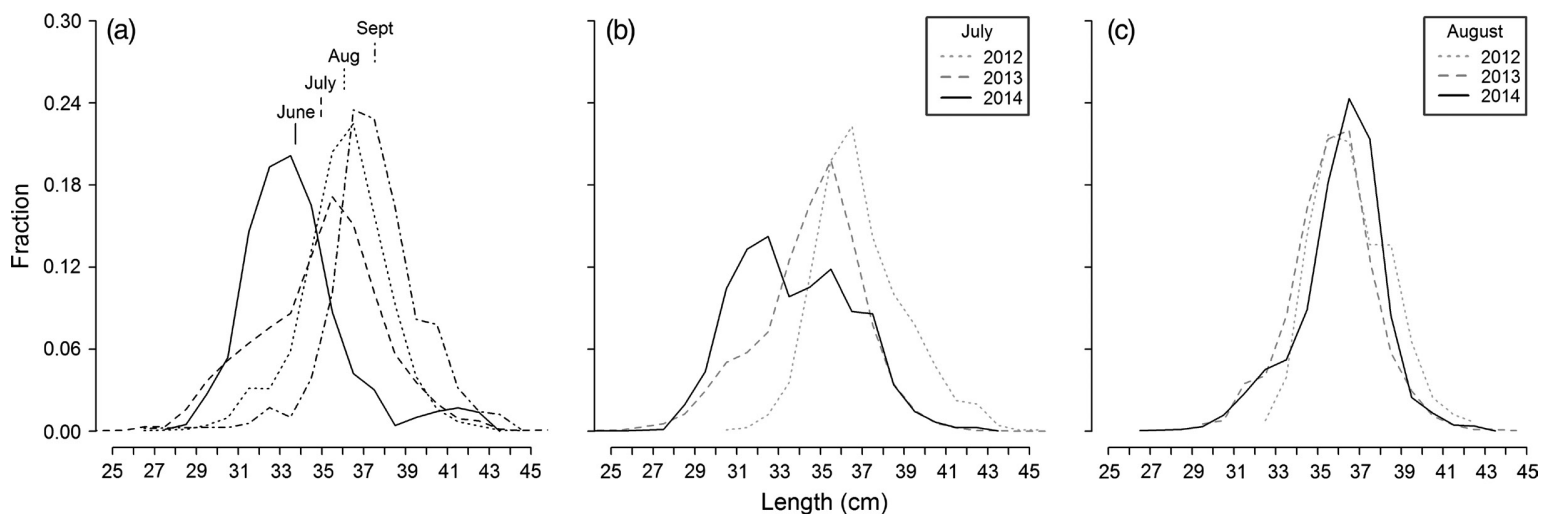

FIG. 3. Length distributions of mackerel caught in the commercial trawl fishery in Greenland in 2012-2014. (a) Mean length and length distribution by month, (b) length distribution in July by year, (c) length distribution in August by year.

numbers in waters as cold as $5.9^{\circ} \mathrm{C}$. The lower bound of the optimal temperature range for mackerel in southeast Greenland appeared to be $\sim 8.5^{\circ} \mathrm{C}$ (Fig. 5 and Appendix S2). In the present study, $6.0^{\circ} \mathrm{C}$ and $8.5^{\circ} \mathrm{C}$ were therefore used as thresholds for potential mackerel occurrence and available mackerel habitat, respectively.

Waters sufficiently warm for mackerel dominated the surface from the Denmark Strait in southeast Greenland to Nuuk in southwest Greenland in mid-summer 2014 (Fig. 2). The size of the available mackerel habitat (mean SST in $1-12$ August $>8.5^{\circ} \mathrm{C}$ ) was estimated to $452,000 \mathrm{~km}^{2}$.

\section{Available habitat in the past}

In recent years, the summer temperature has been record high in the Irminger Current and this has increased the size and seasonal duration of the available habitat for mackerel.

Mean SST in July-August in the mackerel fishing area in southeast Greenland $\left(63-64^{\circ} \mathrm{N}, 31-32^{\circ} \mathrm{W}\right)$ were above $6^{\circ} \mathrm{C}$ in all summers since 1870 and above $8.5^{\circ} \mathrm{C}$ in the vast majority of summers (Fig. 6a, solid red lines). This area has therefore been an available mackerel habitat according to temperature throughout most of the last $145 \mathrm{yr}$. The seasonal duration of the available mackerel habitat was 2-3 months in most years during warm decades such as 1870-1910 and 1930-1970 (Fig. 6b and Appendix S5a), but only 2 months in cold periods like 1920-1930 and 1970-1995. Since 1998, warming has increased the length of the season to 3-4 months in the period June to October. South of Greenland $\left(57-58^{\circ} \mathrm{N}, 4445^{\circ} \mathrm{W}\right)$, SST was lower and the length of the available season was on average 0.3 months prior to 1998 . This has increased to $1-2$ months in July-September in the most recent years (Figs. $6 \mathrm{~b}$ and 7). In southwest Greenland $\left(60-61^{\circ} \mathrm{N}, 53-54^{\circ} \mathrm{W}\right)$, the coldest of the three focus areas, mean monthly SST only exceeded $8.5^{\circ} \mathrm{C}$ in August in a few years before 1998. This has become common in the most recent years (Fig. 6b and Appendix S5c). The size of the available mackerel habitat (area of ocean surface with mean SST in July-August $>8.5^{\circ} \mathrm{C}$ ) ranged from 6,000 to $407,000 \mathrm{~km}^{2}$, with a substantial increase in the last decade (Fig. 6c).

\section{Available habitat in the future}

A warming trend was projected in RCP 4.5 and 8.5, with $0.5^{\circ} \mathrm{C}$ and $1.0^{\circ} \mathrm{C}$ increase from 2014 to 2090 , respectively (Fig. 6a). These long-term climate projections are designed to simulate the climate trends associated with the level of greenhouse gas in the atmosphere as well as to include modes of internal climate variability. That said,

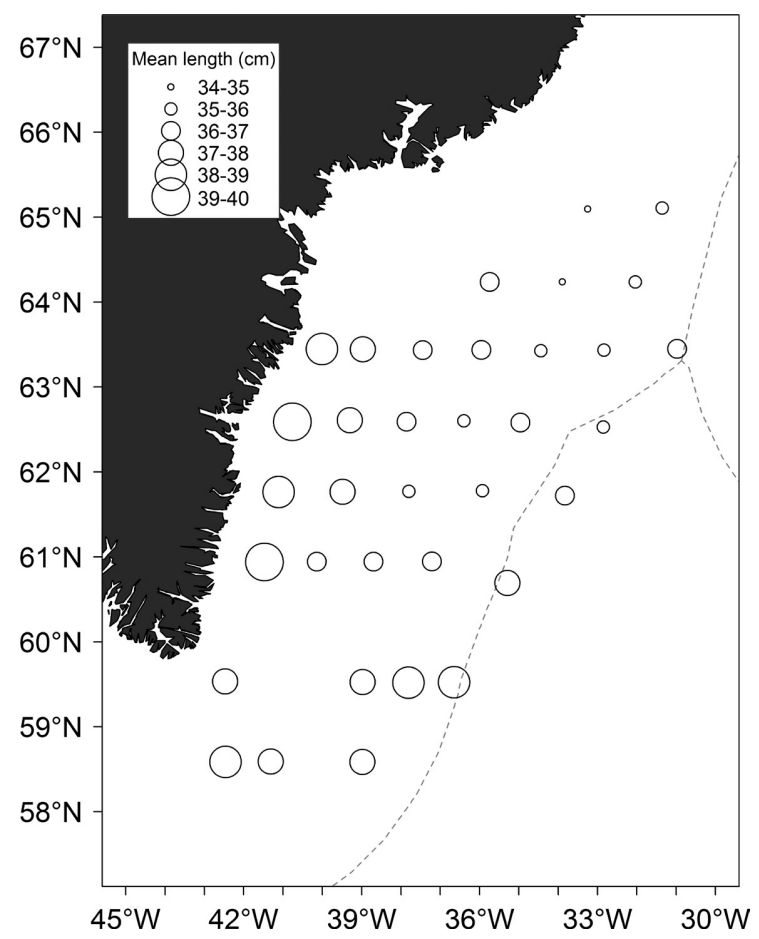

FIG. 4. Mean length of mackerel caught in the International Ecosystem Summer Survey in the Nordic Seas (IESSNS) survey in Greenland in 2014 
the timing of simulated past climate events may not overlap in time with historical observations, as specific years are only associated with the level of remote forcing (e.g., greenhouse gas concentrations). The retrospective performances of the climate models can therefore be quite different when compared with historical observations and may differ between models. Hindcasts from climate models predicted up to $1.8^{\circ} \mathrm{C}$ colder or $5.9^{\circ} \mathrm{C}$ warmer temperatures than observed in the summer months (JulyAugust) in the mackerel fishing area southeast of Greenland $\left(59.9-61.1^{\circ} \mathrm{N}, 52.9-54.1^{\circ} \mathrm{W}\right)$ in $1982-2013$ (Table 1 column " $\overline{\Delta T}$ "). Future SST scenarios calculated as the mean of multiple model outputs could therefore differ substantially depending on the selection of models. Trends were therefore examined instead of absolute values by bias correcting the model specific climatological differences between hind casts and observations. Values used for bias correction are provided in Table 1 column $\overline{\Delta T}$ and model selection is described in Appendix S4.

The spatial and seasonal aspects of the projected multimodel mean SST were examined by extending the observed time series plot in Figs. 6b,c and 7 from 2014 to 2100. The results suggest a substantial extension of the seasonal duration of the available season in all three areas (Figs. 6b and 7, Appendix S5), as well as a substantial geographical expansion of the available habitat (Fig. 6c).

The cold East Greenland Current (EGC) north of $\sim 66^{\circ} \mathrm{N}$ was predicted to remain cold and inaccessible for mackerel under the RCP 8.5 scenario (Fig. 8). However, the coastal surface current south of $66^{\circ} \mathrm{N}$ was suggested to become considerably warmer, allowing for mackerel presence $\left(>6^{\circ} \mathrm{C}\right)$.

\section{Discussion}

Mackerel has migrated into Greenlandic waters in recent years and has occupied an available habitat that, at the same time, has expanded to a historically large area and long season due to warming. This change in migration pattern was followed by a rapid development of a largescale fishery of substantial importance for the national economy of Greenland. Climate projections suggested how the available mackerel habitat may expand further in space and time.

The temperature preferences of mackerel found in the present study are in accordance with previous studies. Mackerel in the Norwegian Sea were rarely observed in waters colder than $\sim 6^{\circ} \mathrm{C}$, and were most abundant between $8^{\circ} \mathrm{C}$ and $13^{\circ} \mathrm{C}$ (Utne et al. 2014, Berge et al. 2015). We suggest that temperature played an important role in limiting the northwestern migration in the recent years, because we found mackerel in most localities up to the polar front. The mackerel had thus realized the entire available habitat, and (unlike previous decades) became directly affected by the changing size and seasonal duration of the available habitat in Greenland. These events in Greenlandic waters happened during a general increase in abundance of northwest-migrating mackerel in the Northeast Atlantic

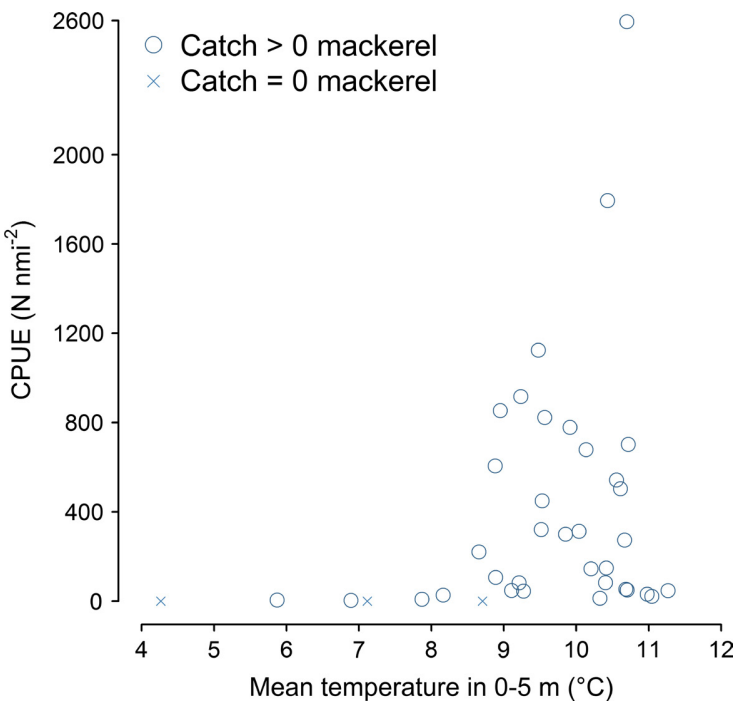

FIG. 5. Catch rates by surface temperatures $(0-5 \mathrm{~m})$ in southeast Greenland in 2014. Data from pelagic trawling and Sea-Bird CTD casts during the IESSNS survey.

(Astthorsson et al. 2012, ICES, 2014; Nøttestad et al. 2015b; Jansen, in press). While climate may have played an important role for the general direction and abundance of the migrating mackerel, it was likely driven by a complex suite of events taking place outside our study area. A range of possible drivers such as stock size, food, age/length structure, and location of spawning has been suggested to interact with the temperature effect (ICES 2013). Disentangling these effects and explaining more of the variation in mackerel migration is the aim of several ongoing data collection efforts and upcoming research projects. However, longer time series with more contrasting situations may be needed before this can be resolved. In summary, mackerel migrated to a new northwestern frontier in Greenlandic waters taking advantage of the available habitat at a time in history when warming expanded the habitat to a historically large area and long season.

Despite a substantial data collection effort, we did not delimit the entire outer edge of the distribution area or fishing season with zero-catches. The largest mackerel normally arrive to the feeding grounds first and leave last (Jansen and Gislason 2011). This pattern was consistently not observed at the beginning of the fishing seasons (Fig. 6a) in east Greenland. The reason for this discrepancy could be that the first and largest mackerel had passed the fishing area before the fishing was initiated. SST in late May and early June appeared to support this hypothesis (Appendix S4). Alternatively, the discrepancy could be a consequence of differences in size-selection of the fishery between months. However, the fishery was done by some of the same pelagic trawlers that fished during the rest of the season, so we do not consider this to be a likely explanation.

The largest mackerel not only delimit the season, they are also indicative of the spatial frontier as they migrate 

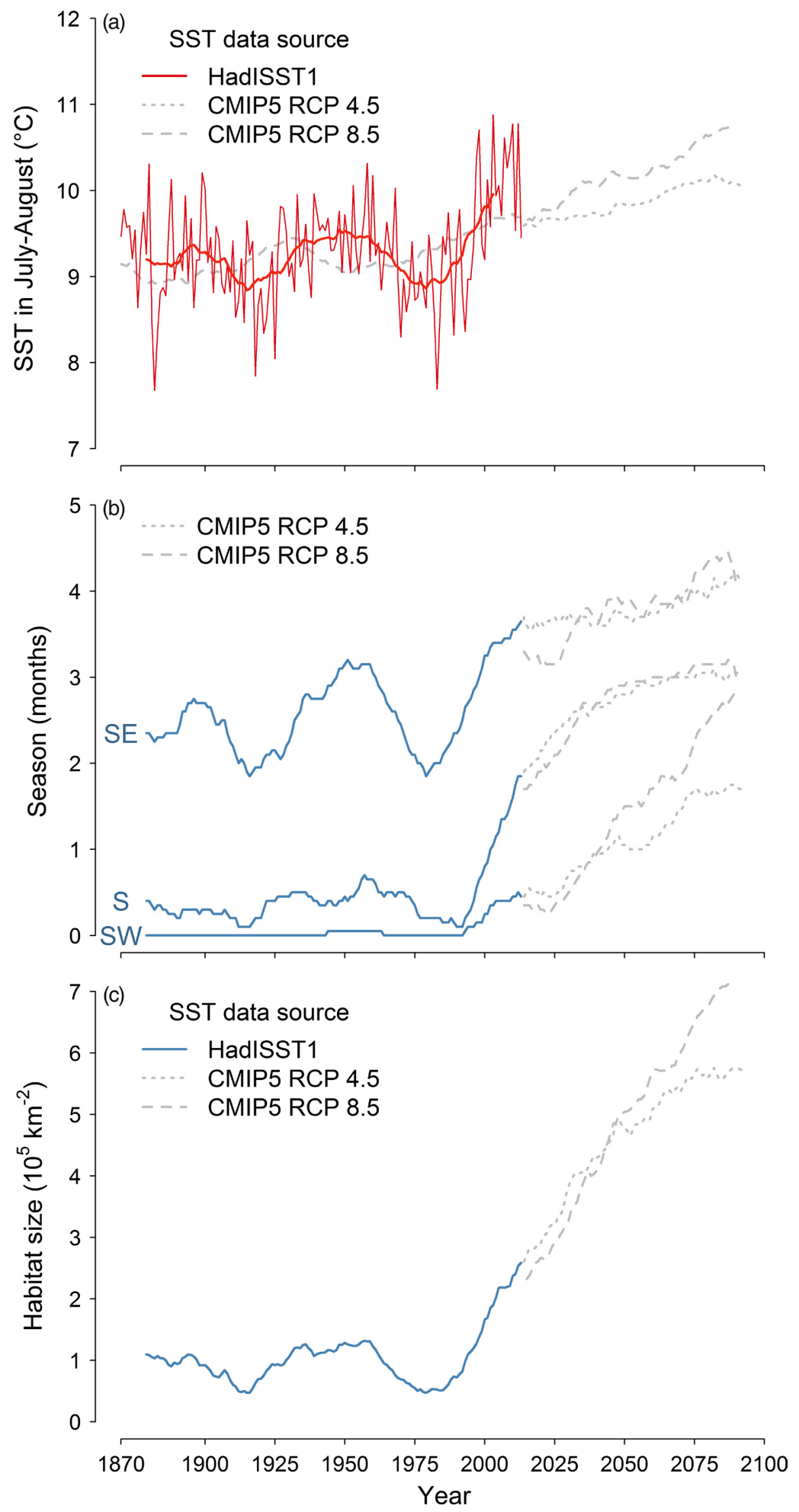

FIG. 6. SST and available mackerel habitat from 1870 to 2100. (a) SST in July-August in the mackerel fishing area in southeast Greenland (Irminger Current), (b) seasonal length of the available habitat (number of months where mean SST $>8.5^{\circ} \mathrm{C}$ ), in southeast, south, and southwest Greenland, respectively, as modeled by two climate-change scenarios (see Materials and Methods: Hydrographic data). (c) Size of the available habitat in July-August. The lines indicate 20-yr running means, except the thin line in (a) that indicates annual values. 


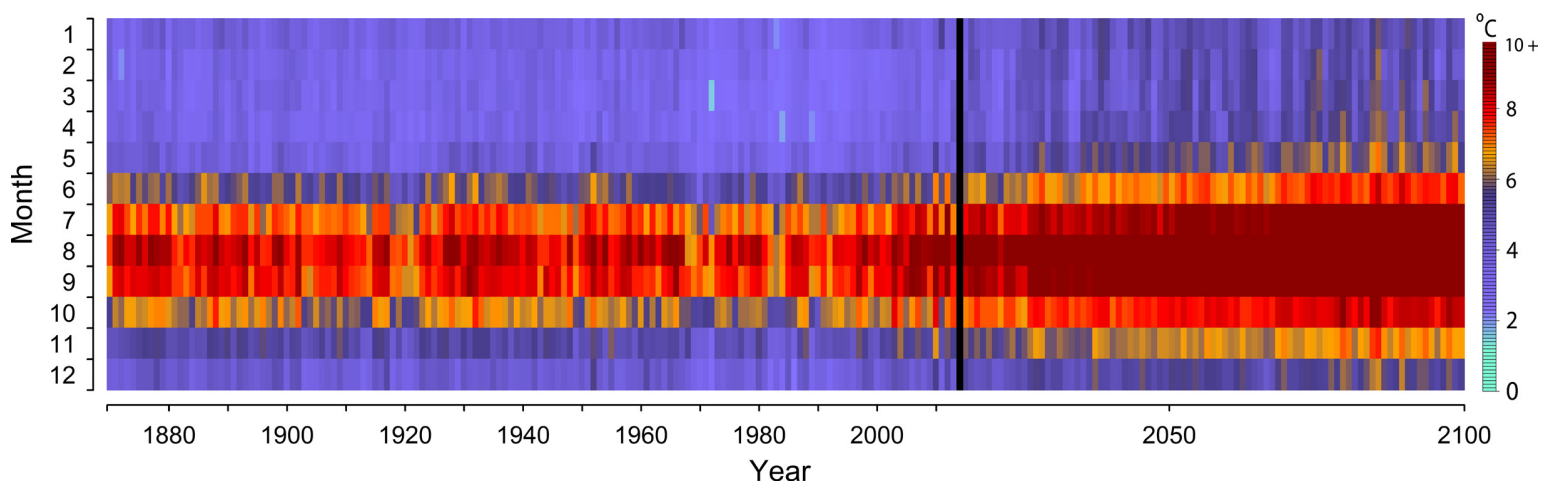

FIG. 7. SST by month from 1870 to 2100 south of Greenland. Black bar indicates 2014. Observation-based historic HadISST1 data and future prediction for RCP 8.5 scenario. "Warm" colors (orange-red) indicate potential mackerel presence $\left(>6^{\circ} \mathrm{C}\right)$, and dark red colors indicate mackerel habitat $\left(>8.5^{\circ} \mathrm{C}\right)$.

furthest away from the spawning grounds and into cooler waters along the polar front (Nøttestad et al. 1999). This was observed in the survey in 2014 where the largest mackerel were caught along the polar front between $61^{\circ}$ and $64^{\circ} \mathrm{N}$ (Figs. 2 and 4). Smaller mackerel were caught along the south and southeastern edges of the survey.

The lack of large mackerel and empty hauls along these edges, combined with satellite observations of SST above $8.5^{\circ} \mathrm{C}$ further to the west, south, and southeast, indicate that mackerel could have been present in parts of these unsampled oceanic areas. The hypothesis of mackerel in oceanic waters off southwest Greenland was furthermore supported by two observations in fjords in southwest Greenland. Judging from the SST, they likely reached the warm water in the fjords from the warm oceanic waters off southwest Greenland, because the coastal current along southwest and south Greenland is too cold for mackerel migration (Fig. 2). Presence of mackerel in the warm international waters southeast of Greenland's EEZ was also possible. However, pelagic summer surveys south of Iceland have consistently observed the southern edge of the mackerel distribution at $\sim 62^{\circ} \mathrm{N}$ (Nøttestad et al. 2015b). New scientific investigations including data collection campaigns in Greenlandic and international waters are needed to resolve these issues.

The precision and certainty of the swept area estimate of $1164 \mathrm{kt}$ of mackerel in Greenland depends on the pelagic trawl survey's ability to catch mackerel in an unbiased and consistent way. Standardization and quality assurance of the gear, rigging, and operation has therefore been done to ensure consistent catchability (Valdemarsen et al. 2014). Nevertheless, interactions between the gear and the mackerel may have biased our estimate. Two sources of bias could be substantial (Peña 2014, Nøttestad et al. 2015a, b). First is horizontal herding. The trawl was towed on one side of the ship wake. This is the standard procedure because mackerel avoid the wake. However, when the mackerel swim away from the wake, then the density will be higher around the wake. This way of herding the mackerel into the path of the trawl may therefore have led to overestimation of the density. Second is vertical avoidance of the trawl, which may have led to underestimation of the density if mackerel were located under or dove under the approaching trawl opening. The catchability factor $(q)$ may thus be above or below 1 , however, it is currently not possible to estimate $q$, so we assumed $q=1$ for the present study. Finally, it should be noted that the NEA mackerel stock size has been estimated by ICES to be lower than the total estimate from the IESSNS survey in the Nordic Seas, thus suggesting that $q$ is below 1 .

Our results indicated that the main fishing area in east Greenland had, on a smaller scale, been an available mackerel habitat according to temperature in historic times. Human activities in this remote area have been very limited before the last decades. It is therefore possible that mackerel have been present, but unnoticed. More historic information exists from Icelandic waters close to east Greenland. Mackerel have been reported several times through history in North Icelandic waters, where the first documented records are from 1900 (Astthorsson et al. 2012). To migrate from the spawning areas to North Iceland, mackerel have to go clockwise around Iceland because of the cold east Icelandic current. The mackerel that reached North Icelandic waters had therefore migrated along the same route, just longer, than if they had migrated to the present fishing area in east Greenland.

Projecting future habitats requires climate models that are able to capture observed climate variability of the past and provide conservative predictions of future scenarios. The current suite of available climate models, such as the IPCC-class models used herein, is of relatively coarse-scale resolution in the ocean $\left(1^{\circ} \times 1^{\circ}\right)$ and therefore unable to resolve mesoscale physical features such as eddies, fronts, and upwelling, which is important for the stratification of the water column and biological production. However, for the large-scale physical and biological seasonal and annual variability, the models, and in particular multi-model ensembles, perform relatively 


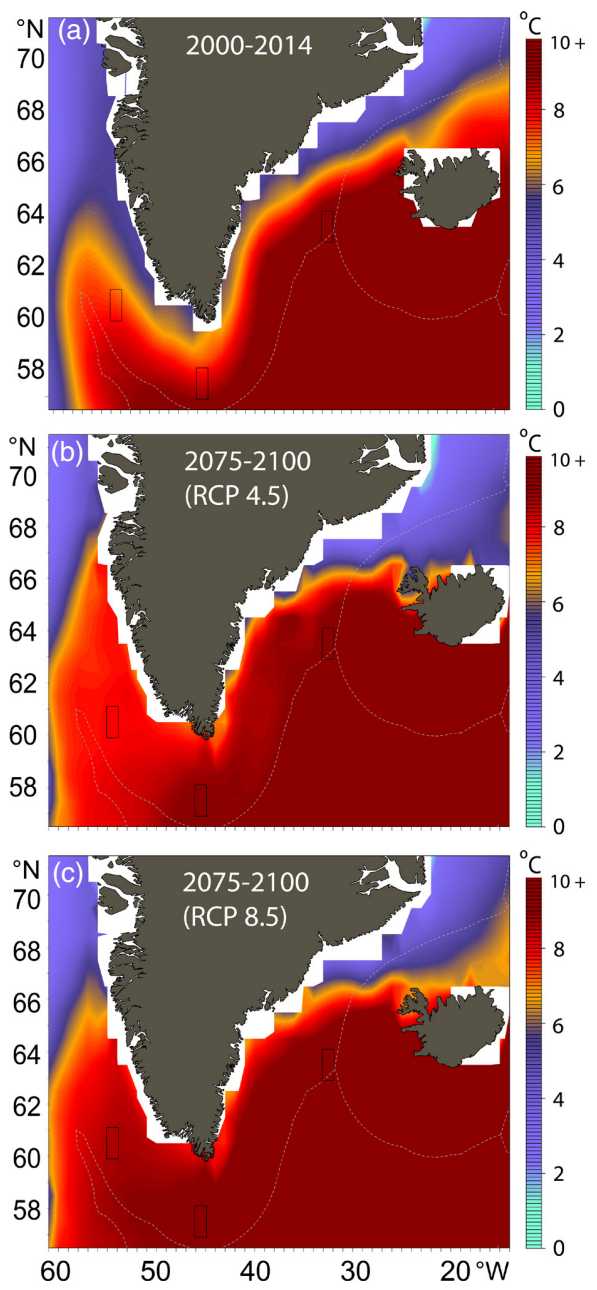

FIG. 8. SST around Greenland in July-August. (a) Mean observed SST from 2000 to 2014, (b, c) mean projected SST for 2075-2100 for the RCP 4.5 and RCP 8.5 scenarios, respectively. "Warm" colors (orange-red) indicate potential mackerel presence $\left(>6^{\circ} \mathrm{C}\right)$, and dark red colors indicate mackerel habitat $\left(>8.5^{\circ} \mathrm{C}\right)$.

well (Reichler and Kim 2008). The area covering the Denmark Strait to the Labrador Sea does reveal some contradicting results when comparing SST projections from different climate models with historic observations (our results; Steinacher et al. 2010, Kristiansen et al. 2014). Still, the majority of models agree that for the east Greenland region, the ocean temperature will increase, and the mixed layer depth will shallow, while total integrated annual mean primary production and biomass will most likely decrease (Steinacher et al. 2010, Kristiansen et al. 2014).

The habitat expansion by mackerel into Greenlandic waters is likely having consequences for food webs and species interactions within the ecosystem. Mackerel has functional roles in marine ecosystems as both a major zooplanktivore and as a prey for higher trophic levels (Trenkel et al. 2014). The occurrence of a high biomass of mackerel may therefore have important consequences on especially the plankton. Such effects may cascade onto other zooplanktivores, such as whales. The mackerel may also be followed by a suite of predators leading to a trophic cascade involving new or formerly rare species into the east Greenland region. One predator which most likely followed and perhaps pursued the mackerel into Greenland waters, and ended up as bycatch in mackerel fisheries, is bluefin tuna (Thunnus thynnus) (MacKenzie et al. 2014). Given our projections of how future climate change could affect ocean conditions in this region, the intensity of these ecosystem effects can be expected to grow in magnitude.

If the predicted scenario with warm surface waters in mid-summer in the coastal region off south Greenland (south of $66^{\circ} \mathrm{N}$ ) should become reality, then it will likely have important consequences for the coastal ecosystem, including key species such capelin (Mallotus villosus), birds, and seals (Frederiksen et al. 2012). This would affect the traditional subsistence hunt for marine mammals and birds and consequently the lifestyle of the local population (Frederiksen et al. 2012).

Some of the expected effects of climate change on marine ecosystems near Greenland could, like the mackerel, have additional positive consequences for its fishery-dependent communities. For example, if species richness of fish and shellish communities increases as temperatures rise, then the overall diversity of possible exploitable species will also likely increase. This in turn should reduce the current dependence of local fisherybased economies on a small number of species and make these economies and communities more resilient to declines of single species (Frank et al. 2007). In general in large marine ecosystems, fishery yields tend to be more stable and higher when supported by a larger number of species (Worm et al. 2006).

The present study is so far the most extreme case of a climate change-related biotic shift of economic importance for an entire nation. Most previous studies of marine climate change impacts have presented future scenarios of how climate change could affect resource distributions and ecosystem services in different geographic regions (Barange et al. 2014, Cheung et al. 2015), or have documented changes in species compositions but not the economic consequences (IPCC 2014, Gattuso et al. 2015).

Living marine resources are particularly important for the Greenlandic economy, and the recent appearance of mackerel is contributing to this importance. Fishery resources represent $93 \%$ of the total export value of Greenland: before the arrival of mackerel, northern shrimp (Pandalus borealis) typically constituted more than half of this, while the remaining part was dominated by cod (Gadus morhua) and Greenland halibut (Reinhardtius hippoglossoides) (Greenland Statistics 2014). The Greenlandic economy is therefore sensitive to changes in abundance and availability of these relatively few fishing resources. The stock size of northern shrimp is decreasing, as is the quota (NAFO \& ICES 2014). The mackerel fishery is therefore expected to become the 
quantitatively largest in near future. The appearance of mackerel in east Greenland consolidates the role of renewable resources and is extremely important for the Greenlandic economy, which as noted previously, is presently heavily dependent on living marine resources.

If the global warming trend continues, then we can expect to see many changes in nature that will affect human livelihood throughout the globe. Some of these changes could, as shown in this study, be perceived as positive on a local scale. However, the negative impacts of climate change are expected to be manifold and dominating (IPCC 2014). The positive cases should therefore not be cherry-picked and misused as arguments against timely and effective mitigation of climate change.

\section{ACKNOWLEDGMENTS}

We wish to thank the lab and field assistants from MRI and GINR that sampled and measures the many mackerel analyzed in the present study. We would also like to thank the Greenlandic fishermen and the crew onboard R/V Árni Friðriksson for providing and handling the sampling platforms in a challenging environment. This work was funded by the Danish Government through the program "Marine climate in the North Atlantic and its effects on plankton and fish."

\section{Literature Cited}

Allen, E. J. 1897. Report on the present state of knowledge with regard to the habits and migrations of the mackerel Scomber scombrus. Journal of the Marine Biological Association of the UK 5:1-29.

Astthorsson, O. S., H. Valdimarsson, A. Gudmundsdottir, and G. J. Oskarsson. 2012. Climate-related variations in the occurrence and distribution of mackerel (Scomber scombrus) in Icelandic waters. ICES Journal of Marine Science 69:1289-1297.

Barange, M., et al. 2014. Impacts of climate change on marine ecosystem production in societies dependent on fisheries. Nature Climate Change 4:211-216.

Bazilchuk, N. 2010. Mackerel wars. Frontiers in Ecology and the Environment 8:397.

Beaugrand, G. 2014. Pelagic ecosystems and climate change. Pages 141-150 in B. Freedman, editor. Global environmental change. Springer, Dordrecht, the Netherlands.

Berge, J., K. Heggland, O. J. Lønne, F. Cottier, H. Hop, G. W. Gabrielsen, L. Nøttestad, and O. A. Misund. 2015. First records of Atlantic Mackerel (Scomber scombrus) from the Svalbard Archipelago, Norway, with possible explanations for the extension of its distribution. Arctic 68:54-61.

Cendrowicz, L. 2010. The mackerel wars: Europe's Fish Tiff with Iceland. Time 27:1.

Cheung, W. W., R. D. Brodeur, T. A. Okey, and D. Pauly. 2015. Projecting future changes in distributions of pelagic fish species of Northeast Pacific shelf seas. Progress in Oceanography 130:19-31.

Collins, M., et al. 2013. Long-term climate change: projections, commitments and irreversibility. Pages 1029-1136 in T. F. Stocker et al., editors. Climate change 2013: the physical science basis. Contribution of Working Group I to the Fifth Assessment Report of the intergovernmental panel on climate change. Cambridge University Press, Cambridge, UK.

Frank, K. T., B. Petrie, and N. L. Shackell. 2007. The ups and downs of trophic control in continental shelf ecosystems. Trends in Ecology \& Evolution 22:236-242.
Frederiksen, M., D. Boertmann, F. Ugarte, and A. Mosbech. 2012. South Greenland. A strategic environmental impact assessment of hydrocarbon activities in the Greenland sector of the Labrador Sea and the southeast Davis Strait. Scientific report from DCE-Danish Centre for Environment and Energy, Pages 1-220.

Gattuso, J., A. Magnan, R. Billé et al. 2015. Contrasting futures for ocean and society from different anthropogenic $\mathrm{CO}_{2}$ emissions scenarios. Science 349:aac4722. http://science.sciencemag.org/content/349/6243/aac4722

Greenland Statistics. 2014. Udenrigshandel, 1, http://www.stat.gl ICES. 2013. Report of the ad hoc group on distribution and migration of Northeast Atlantic Mackerel (AGDMM). ICES CM 2013/ACOM:58.

ICES. 2014. Report of the working group on widely distributed stocks (WGWIDE). ICES CM 2014/ACOM:15.

IPCC. 2014. Climate change 2014: synthesis report. Pages 151 in Core Writing Team, R. K. Pachauri, and L. A. Meyer, editors. Contribution of Working Groups I, II and III to the Fifth Assessment Report of the intergovernmental panel on climate change. IPCC, Geneva, Switzerland.

Jansen, T. 2014. Pseudocollapse and rebuilding of North Sea mackerel (Scomber scombrus). ICES Journal of Marine Science 71:299-307.

Jansen, T. 2016. First-year survival of North East Atlantic Mackerel (Scomber scombrus) from 1998 to 2012 appears to be driven by availability of calanus - a preferred copepod prey. Prog. Oceanogr. 25:457-469. http://dx.doi.org/10.1111/ fog. 12165

Jansen, T., T. Brunel, A. Campbell, C. Main, L. Readdy, and L. Nøttestad. 2009. Northeast Atlantic mackerel-quality handbook for assessment. ICES CM 2009/ACOM:12/Stock annex A, Pages 1-21, International Council for the Exploration of the Sea, Copenhagen, Denmark.

Jansen, T., and F. Burns. 2015. Density dependent growth changes through juvenile and early adult life of North East Atlantic mackerel (Scomber scombrus). Fisheries Research 169:37-44

Jansen, T., A. Campbell, C. J. Kelly, H. Hátún, and M. Payne. 2012. Migration and fisheries of North East Atlantic Mackerel (Scomber scombrus) in autumn and winter. PLoS ONE 7:1-9.

Jansen, T., and H. Gislason. 2011. Temperature affects the timing of spawning and migration of North Sea mackerel. Continental Shelf Research 31:64-72.

Jansen, T., and H. Gislason. 2013. Population structure of Atlantic mackerel (Scomber scombrus). PLoS ONE 8:1-10.

Jensen, F., H. Frost, T. Thøgersen, P. Andersen, and J. L. Andersen. 2015. Game theory and fish wars: the case of the Northeast Atlantic mackerel fishery. Fisheries Research 172:7-16.

Jervelund, C., and N. C. Fredslund. 2013. Fiskeriets økonomiske fodaftryk i Grønland. Copenhagen Economics 1:1-40.

Kristiansen, T., C. Stock, K. F. Drinkwater, and E. N. Curchitser. 2014. Mechanistic insights into the effects of climate change on larval cod. Global Change Biology 20:1559-1584.

MacKenzie, B. R., M. R. Payne, J. Boje, J. L. Høyer, and H. Siegstad. 2014. A cascade of warming impacts brings bluefin tuna to Greenland waters. Global Change Biology 20:2484-2491.

Nøttestad, L., J. Giske, J. C. Holst, and G. Huse. 1999. A length-based hypothesis for feeding migrations in pelagic fish. Canadian Journal of Fisheries and Aquatic Science $56: 26-34$.

Nøttestad, L., J. Diaz, H. Penã, H. Søiland, G. Huse, and A. Fernö. 2015a. Feeding strategy of mackerel in the Norwegian 
Sea relative to currents, temperature, and prey. ICES Journal of Marine Science 73:1127-1137.

Nøttestad, L., et al. 2015b. Quantifying changes in abundance, biomass and spatial distribution of Northeast Atlantic (NEA) mackerel (Scomber scombrus) in the Nordic Seas from 2007 to 2014. ICES Journal of Marine Science 73:359-373.

Overholtz, W. J., J. A. Hare, and C. M. Keith. 2011. Impacts of interannual environmental forcing and climate change on the distribution of Atlantic mackerel on the U.S. Northeast Continental Shelf. Marine and Coastal Fisheries 3:219-232.

Peña, H. 2014. Acoustic measurements of mackerel close to the sea surface for evaluating the performance of the pelagic trawling. ICES CM 2014/ACOM:43: WD1-18.

R Core Team. 2013. R: a language and environment for statistical computing. R Foundation for Statistical Computing, Vienna, Austria. http://www.R-project.org/

Radlinski, M. K., M. A. Sundermeyer, J. J. Bisagni, and S. X Cadrin. 2013. Spatial and temporal distribution of Atlantic mackerel (Scomber scombrus) along the northeast coast of the United States, 1985-1999. ICES Journal of Marine Science 70:1151-1161.

Rayner, N., D. Parker, E. Horton, C. Folland, L. Alexander, D. Rowel, E. Kent, and A. Kaplan. 2003. Global analyses of sea surface temperature, sea ice, and night marine air temperature since the late nineteenth century. Journal of Geophysical Research-Oceans 108:1-22.
Reichler, T., and J. Kim. 2008. How well do coupled models simulate today's climate? Bulletin of the American Meteorological Society 89:303-311.

Reynolds, R. W., T. M. Smith, C. Liu, D. B. Chelton, K. S. Casey, and M. G. Schlax. 2007. Daily high-resolution-blended analyses for sea surface temperature. Journal of Climate 20:5473-5496.

Steinacher, M., et al. 2010. Projected 21st century decrease in marine productivity: a multi-model analysis. Biogeosciences 7:979-1005.

Trenkel, V. M., et al. 2014. Comparative ecology of widelydistributed pelagic fish species in the North Atlantic: implications for modelling climate and fisheries impacts. Progress in Oceanography 129:219-243.

Utne, K. R., A. Ólafsdóttir, G. J. Óskarsson, A. Slotte, A. Mork, J. A. Jacobsen, S. Jonsson, and L. Nøttestad. 2014. Environmental conditions and horizontal distribution of mackerel during summer feeding. ICES C.M. 2014/ACOM: 43:WD, International Council for the Exploration of the Sea, Copenhagen, Denmark.

Valdemarsen, J. W., et al. 2014. Swept area estimation of the North East Atlantic mackerel stock using a standardized surface trawling technique. Working document to ICES Benchmark Workshop on Pelagic Stocks (WKPELA), 17-21 February 2014, Pages 1-17, Copenhagen, Denmark.

Worm, B., et al. 2006. Impacts of biodiversity loss on ocean ecosystem services. Science (New York, N.Y.) 314:787-790.

\section{SUPPORTING INFORMATION}

Additional Supporting Information may be found online at: http://onlinelibrary.wiley.com/doi/10.1002/eap.1384/suppinfo

\section{Data Avallability}

Data associated with this paper have been deposited in Dryad: http://dx.doi.org/10.5061/dryad.1d808. 